18. Абдурахманов Д.Б., Гапуров Ш.А., Закриев Б.Б. Ранние этапы российско-чеченских политических взаимоотношений (XVI-XVII вв.) // Чеченцы в сообществе народов России. Т. 1. Назрань, 2008. С. 3-4.

19. Моя Чечено-Ингушетия: краеведческое пособие по истории для учащихся средней школы Чечено-Ингушской АССР / под ред. Н.А. Тавакаляна. Грозный: Чеч.-Инг. кн. изд-во, 1970. 138 с.
20. Гапуров Ш.А. Северный Кавказ в политике России в начале XIX века (1801-1818 годы). Нальчик: Эль-Фа, 2004. 489 с.

21. Магарамов Ш.А. Восточный Кавказ во внешней политике России, Ирана и Турции в 50-70-е гг. XVII в. // Чеченцы в сообществе народов России. Т. 2. Назрань, 2008. С. 186-193.

\title{
THE RUSSIAN-CHECHEN RELATIONS IN XVI-XVII CENTURIES
}

(C) 2017

Tovsultanov Rustam Alhazurovich, candidate of history sciences, associate professor of Modern and Contemporary History Department Chechen State University (Grozny, Russian Federation)

Galimova Lilia Nadipovna, doctor of history sciences, professor of Humanities and Social Sciences Department Ulyanovsk Institute of Civil Aviation named after chief Marshal of aviation B.P. Bugaev

(Ulyanovsk, Russian Federation)

Ozdamirova Eliza Musatovna, senior teacher of Modern and Contemporary History Department Chechen State University (Grozny, Russian Federation)

Abstract. The following paper investigates the Russian-Chechen relations in XVI-XVII centuries. The authors note that the Caucasus was in the sphere of Russian foreign policy at the time of the Russian centralized state formation. With the annexation of the Astrakhan khanate, Russia came to the Caucasus border and the Caucasian direction started to occupy a leading place in the Eastern policy of the tsarist government. The Caucasus in the XVI century was an object of a tense struggle between the two most powerful States of the then Middle East - Ottoman Empire and Safavid Iran - and at the same time a bridgehead, where there was a constant threat to the southern outskirts of Russia from these States and the Crimean khanate. The strengthening of Russia on the Caucasian lands could become the most reliable means to ensure the safety of the South of Russia. So in the XVII and XVII centuries, the North Caucasus was Russia's military-strategic interest or, in modern language, a geopolitical one. Chechnya came under the influence of Russia in 1567, when the first Russian militarized city Terek in the North Caucasus was founded. For the peoples of the North Caucasus and of Chechnya the appearance of a Russian fortress on their land was of great political importance.

Thus, it was vital for Russia to gain a foothold in the North Caucasus, as the enemy (Iran and Turkey) could do it, which was unsafe for Russia's southern borders. It was during this period (late sixteenth century) when close military and political ties of the Moscow government and the Chechens were established. The Moscow government was interested in Chechnya because of its geographical location - the immediate proximity to the towns of Terek and the fact that its territory was the most convenient means of communication with Georgia.

The relationship between Chechnya and Russia at the end of XVI - first half of XVII century was almost an «ideal model» of a peaceful rapprochement of the Chechen with the Moscow government for those conditions and at that time. The Russian authorities did not interfere in the internal affairs of the Chechen societies, they did not impose their own rules or laws, being satisfied with the results of the hostages, the payment of tribute and, if necessary, temporary military service. This led to the fact that in the XVII century allied relations of Chechnya societies with Russia were established. However, at the end of the XVII century Russian-Caucasian connection was significantly weakened.

Keywords: Caucasus; Russian foreign policy; Russia; Moscow Kingdom; Eastern policy of tsarist government; North Caucasus; Chechnya; Terek; Sunzha; Dagestan; fortress; Moscow; North Caucasian peoples; Russia; Central Asia; Transcaucasia; Turkey; Iran; southern border; Moscow government; Chechens; Russian-North Caucasian relations; political situation; Embassy; Ambassador; citizenship; Russian-Chechen Treaty; oath; policy; relationship.

УДК 94(47).08

\section{УРАЛО-КАСПИЙСКИЙ РЕГИОН КАК ИСТОРИКО-ГЕОГРАФИЧЕСКИЙ ФЕНОМЕН (ХVI - НАЧАЛО ХХ ВВ.)}

(C) 2017

Любичанковский Сергей Валентинович, доктор исторических наук, профессор, заведующий кафедрой истории России,

Оренбургский государственный педагогический университет (г. Оренбург, Российская Федераџия)

Любичанковский Алексей Валентинович, кандидат географических наук, доцент кафедры географии и регионоведения, научный сотрудник

Оренбургский государственный университет, Институт Степи УрО РАН

(2. Оренбург, Российская Федераичи)

Аннотация. В статье предлагается опыт междисциплинарного историко-географического исследования, в главном фокусе которого находится существовавший с XVI в. до начала XX века Урало-Каспийский регион. 
Для задач нашего исследования была проведена оценка освоенческого вектора включения новых земель в орбиту российской цивилизации, анализ формирования Урало-Каспийского региона через оценку геодинамики его культурных ландшафтов, а также охарактеризованы социальные процессы, в нем происходившие. На основе проделанной работы авторы предлагают рассматривать Урало-Каспийский регион как фронтир, существовавший с XVI в. до начала XX века. Для него были характерны ассимиляция русской и ногайской культур на раннем этапе развития, мозаичность и дисперсность структуры этнокультурного пространства, своеобразная культура уральского и оренбургского казачества и характерная для любого фронтира зона особых социальных условий, связанная с идущими на ней процессом освоения. Оренбургская область с ее «расползающейся» региональной идентичностью, в силу нахождения в ней центра исследуемого региона, является единственным «останцом» существовавшего Урало-Каспийской региона. В исторической памяти населения можно выделить пять пространственных образов Оренбургского региона: «плацдарм в Центральную Азию», «цитадель "цивилизаторов"», «опытный полигон для реформ», «объект эксплуатации с огромными ресурсами» и «глухая провинция».

Ключевые слова: фронтир; культурные ландшафты; Урало-Каспийский регион; освоенческий вектор; номадная модель; историко-географическая характеристика; цивилизация; Ногайская орда; ассимиляция; оренбургское казачество; этнокультурное пространство; региональная идентичность.

В настоящее время в исторической науке не так часто встречается межпредметный синтез с географической научной отраслью, что существенно скрадывает и сужает научный анализ многих вопросов, подпадающих под задачи обеих этих наук. Так, например, оценка освоенческого вектора, включение новых земель в орбиту какой-либо цивилизации, с нашей точки зрения, могут и должны рассматриваться не только по отдельности, но и используя трансдисциплинарный синтез. Опыт такого междисциплинарного исследования рассматривается нами на примере историко-географической характеристики культурных ландшафтов Урало-Каспийского региона.

В задачи нашего исследования входил анализ формирования Урало-Каспийского региона через оценку геодинамики его культурных ландшафтов, рассмотрения его освоенческого вектора и оценки социальных процессов, в нем происходящих.

В период с XVI по начало XX веков существовал Урало-Каспийский регион, который отображался в региональной идентичности заполняющего его населения. Этот период в развитии этнокультурного пространства распадается на два этапа: формирование фронтира и его исчезновение в «расползающейся» идентичности региона.

Термин «фронтир» был введен в научный оборот Ф. Тернером, который определил его как «точку встречи дикости и цивилизации» $[1$, с. 18$]$.

В строгом смысле фронтир - это зона освоения, точнее - территория, социальные и экономические условия которой определяются идущим на ней процессом освоения. В США подобную зону освоения часто воспринимают как линию, поскольку освоение территории не слишком задерживалось. Вслед за первопроходцами быстро приходила цивилизация. Фронтир определяли, например, как границу между проданной и «ничейной» землями, границу резерваций, наконец, границу между самыми западными штатами и самыми восточными «территориями» (territory - это название административной единицы с особым статусом; чтобы получить статус штата, та или иная «территория» должна была иметь определенную численность населения). Термин «фронтир» официально применялся также для обозначения линии, ограничивающей территорию с плотностью населения менее двух человек на одну квадратную милю [2, с. 75-89].

Фронтир - зона особых социальных условий, а не граница территории, находящейся под юрисдикцией государства, и уж тем более не граница территории, разведанной его жителями (несмотря на этимологию происхождения самого термина и квазилинейность этой зоны в США). Такие зоны в России легко выделяются: современный Центральный район (Залесская Русь) осваивался русскими в XI-XIV веках, так называемый Русский Север - в XV-XVII веках, современный Черноземный Центр - в XVI-XVII веках, Дон и Северный Кавказ - в XVII - начале XIX века, Урал и Сибирь - в XVII-XVIII веках. Дальний Восток - во второй половине XIX - начале XX века (по периодизации Д.Н. Замятина). Каждую из этих «порций», пусть и чрезвычайно обширную, в соответствующее время можно было считать зоной фронтира, или, по-русски, порубежья [2, с. 75-89].

Ретроспективный анализ процесса включения новых земель в орбиту российской цивилизации позволяет охарактеризовать Урало-Каспийский регион как фронтир, существовавший с XVI в. до конца XVIII века.

Номадная модель освоения Урало-Каспийского региона характерна для этой территории вплоть до окончательного включения в состав российской государственности.

Период, непосредственно предшествующий образованию Урало-Каспийского фронтира, сопровождался ассимиляцией монголо-татар в половецкой среде (XIII в.). В XIV-XV веках в Волго-Иртышском междуречье, а также на пространстве от Арала до Казани сложилась Ногайская орда. Основным занятием ногайцев было кочевое скотоводство, хотя часть ногайцев были оседлыми, занимались торговлей, земледелием, ремесленничеством. К моменту российской колонизации региона к югу от Яика кочевали киргиз-кайсаки (казахи), севернее находились места кочевий башкир. К востоку от Волги и к югу от Самары кочевали калмыки, позже переселившиеся в низовья Волги. Жили здесь и оседлые народы: татары, мещеряки, мордва, черемисы (марийцы), вотяки (удмурты), чуваши и др. [3, с. 4-5].

B XVI веке, в годы правления Ивана IV, произошло завоевание Поволжья. Астрахань была завоевана в 1556 г. После этого в вассальное положение от Российского царства попала Большая Ногайская орда (1557 г.). Контроль над торговыми путями по Волге способствовал включению в социально-экономическое пространство Российского государства территории от Волги до реки Яик (Урал), то есть восточной 
части Ногайской орды, и последовавшей активной колонизации этих земель. Овладение всем волжским торговым путем открыло богатые восточные рынки, крестьяне начали активную колонизацию Поволжья.

С 1557 года Ногайская Орда разделилась на Большую Ногайскую Орду (Большие Ногаи), оставшуюся в Степном Заволжье, и на не пожелавшую признать московский сюзеренитет Малую Ногайскую Орду (Малые Ногаи, Казыев улус, или Кубанская Орда), откочевавшую под руководством Казимирзы на запад в Приазовье и на Кубань [4].

Активная взаимопроникновение и ассимиляция русской и ногайской культур проиллюстрировано, в частности, в картографическом материале Сигизмунда фон Герберштейна в 1549 году на карте Московии, где ногайские татары локализуются и в право, и в левобережной части низовий Волги.

В 1577 русскими войсками был завоеван Сарайчик (столица Ногайской Орды). Ее падению способствовали внутренние смуты, которыми воспользовалось враждебное окружение [4].

Именно с этого времени начал складываться фронтир, который просуществовал до XIX века с установлением сложившейся (в противовес неустойчивой зоне освоения) системы этнокультурного мозаичного пространства.

В начале XVII века ногайские кочевья по обоим берегам Яика до Волги заселили калмыки. В 1628-1630 годах калмыки во главе с Хо-Урлюком напали на Большую Ногайскую Орду и заняли междуречье Волги и Яика [5].

В 1634 году под давлением калмыков ногайцы были вытеснены на Северный Кавказ и вынуждены были кочевать в правобережной зоне Волги с Малой Ногайской ордой.

Упомянем здесь также о начале нынешнего Уральска. «Около 1584 года шесть или семь сот Волжских Козаков выбрали себе жилище на берегах Яика, в местах привольных для рыбной ловли; окружили его земляными укреплениями и сделались ужасом Ногаев, в особенности Князя Уруса, Измаилова сына, который непрестанно жаловался Царю на их разбои и коему Царь всегда ответствовал, что они беглецы, бродяги и живут там самовольно; но Урус не верил и писал к нему: "Город столь значительный может ли существовать без твоего ведома? Некоторые из сих грабителей, взятые нами в плен, именуют себя людьми Царскими"» [6, с. 220-221].

В 1585 году последний «великий атаман» Сибири Матвей Мещеряк и атаман Барабоша, поняв, что более на Волге прежней вольной жизни не будет (из-за построенных на Волге [русско-московских] крепостей), решили увести своих казаков на восток. На территории Большой Ногайской Орды, на реке Яик рядом с устьем реки Илек на острове Кош-Яик, около 700 человек в течение лета построили крепость. Ногайский князь Урус осадил крепость, но потерпел поражение. Так образовалось Яицкое казацкое войско. Основными занятиями яицких казаков были рыболовство, добыча соли, охота. Войско управлялось кругом, который собирался в Яицком городке. Правительство привлекало яицких казаков для охраны юго-восточных границ и военной колонизации, разрешая им прием беглых.
От Оренбургской экспедиции (1734-1744 гг.) начинается массовая российская колонизация региона. Первыми российскими поселенцами были беглые крестьяне, преследуемые правительством раскольники, гонимые за веру сектанты и др. В конце периода в верховьях Урала и его притоков стало оседать казачество [3, с. 4-5].

Оренбургская губерния была основана в 1744 году. Переселение в регион носило волнообразный характер. В конце XVIII века, согласно ревизии 1795 г., в Оренбургской губернии в ее тогдашних границах проживало около 500 тыс. чел. (без учета казахского населения, которое составляло примерно 80-100 тыс. человек). Насчитывалось примерно 100 тыс. башкир. Проживали русские, татары, мордва, чуваши, марийцы, удмурты и калмыки. 36\% населения составляли казаки. Прибывающее нерусское население селилось частично в русских деревнях (чуваши и мордва), частично изолированно (большая часть татар). Оренбуржье стало многонациональным. Преобладала колониальная модель освоения. Колонизация носила как принудительный, так и добровольный характер, сопровождалась экспортом культуры и воспроизводством образа жизни метрополии среди автохтонных народов, привела к расширению границ метрополии. Духовная модель освоения связана с мессианством, с политикой изоляционизма отдельных этнокультурных групп либо с гонениями; чаще всего носила религиозный характер. В сельской местности и в настоящее время встречаются локальные этноконфессиональные сообщества - русские со старообрядческим населением, немецкие (менонитские, баптистские и др.). Однако и в эти поселения проникли сначала отдельные элементы унифицированной «европейской» современной культуры, а позже этнокультурные сообщества трансформировались под воздействием окружающей доминантной культуры $[3$, c. 5].

Во второй половине XIX века новая волна заселения, истоком которой была центральная Россия (Тамбовская, Воронежская, Курская губернии), довела долю русского населения до $55 \%$, и с тех пор и до сегодняшнего дня регион имеет статус «русского коридора» между тюркоязычным мусульманским севером (Башкирия, Татария) и югом (казахские земли). Наиболее интенсивный поток переселенцев направлялся в Бузулукский, Бугурусланский и Оренбургский уезды.

В данный период, в связи с присоединением к империи среднеазиатских земель, регион утрачивает приграничное положение. В 1862 г. Оренбургская крепость была официально упразднена, в 1881 г. в крае было упразднено военно-административное положение. В городах стали активно строиться объекты гражданской архитектуры. Анализ территориальной структуры культурного наследия свидетельствует о том, что процесс освоения территории в этом периоде происходил не только вширь, но и вглубь. Об этом свидетельствует увеличение в доле культурного наследия объектов гражданской архитектуры и культовых зданий, причем не только в крупных населенных пунктах, но и в сельской местности.

В целом на данном этапе сформировалась линейно-узловая территориальная структура расселения. 
Любичанковский С.В., Любичанковский А.В

С отменой крепостного права вся империя, в том числе и Оренбургская губерния, вступила в новый этап развития. Помещики, потерявшие право на эксплуатацию подневольного труда, стали активно привлекать переселенцев-арендаторов. В результате новой волны переселения к началу XX века доля русских составила $70 \%$ населения губернии, башкир $16 \%$, татар $-6 \%$, украинцев $-2,5 \%$ и т.Д. Соответственно возрастала территория, освоенная в русле славянской православной культуры.

Происходит рост городского населения. Наиболее крупным городом не только губернии, но и всего Урала к концу XIX века являлся Оренбург.

Оренбургская область с ее «расползающейся» региональной идентичностью, в силу нахождения в ней центра исследуемого региона, является единственным «останцом» существовавшего Урало-Каспийской региона.

Для анализа исторической памяти населения мы используем понятие «пространственно-лимогенные образы» (лимология - наука о границах). Под ним понимается пространственный образ региона в ментальности населения, связанный с его распространением в определенных границах. Выявление таких образов предполагает синтез исторического анализа с ментальной географией.

Несмотря на ликвидацию Оренбургского генералгубернаторства и военного округа в 1883, ощущение территориальной интеграции Оренбургского региона продолжало долго существовать. Возможно, одной из причин этого было то, что продолжал функционировать оренбургский учебный округ. Это демонстрируют публикации местных краеведов и в начале, и в 20-е, и даже 30-е годы XX века [7].

$\mathrm{B}$ исторической памяти населения можно выделить пять пространственных образов Оренбургского региона: «плацдарм в Центральную Азию», «цитадель "цивилизаторов"», «опытный полигон для реформ», «объект эксплуатации с огромными ресурсами» и «глухая провинция».

«Плацдарм в Центральную Азию». По мнению К. Мацузато, историческое происхождение этого территориального образа было связано с тем, что в «проекте Кириллова» (1730-е гг.) ему было уделено особое внимание [8, с. 19]. Эта тенденция усилилась и тем, что известный краевед А.И. Добросмыслов опубликовал двухтомную коллекцию правительственных решений и других юридических документов, касающихся Оренбургского региона, изданных в течение 1734-1736 гг. и хранящихся в городе Тургай [9]. Несомненно, обладать такими коллекциями очень удобно для историков. В действительности, как только началась экспедиция, Иван Кириллов столкнулся с башкирским восстанием, и ему пришлось вернуться к традиционной правительственной политике для того, чтобы объединить оборону этого региона, отказавшись от амбициозного проекта создания нового города-крепости (Оренбург) - огромного торгового центра, объединяющего Китай, Индию, Центральную Азию и Европу. Современное представление предлагает рассмотреть политику правительства по отношению к Урало-Каспийскому региону в течение XVIII века в более широком контексте, а не через призму «проекта Кириллова» [10].
«Цитадель "цивилизаторов"». Оренбургские местные чиновники пытались сделать Оренбург цитаделью «цивилизаторов» (этим статусом обычно наделяли Казань). В первой половине XIX века православная миссионерская деятельность в основном предназначалась для староверцев и язычников среди инородцев. И только в 1850-х гг. стала серьезно обсуждаться угроза ислама. Например, русские чиновники начали отмечать, что киргизы (казахи), у которых была склонность к язычеству и до их интеграции в Российскую империю, несмотря на то, что официально были мусульманами, фактически были исламизированы под российским правлением. Поэтому введение епархии, имеющей дело в основном с антиязыческой и миссионерской деятельностью в многоконфессиональном Оренбурге, отвечало духу той эпохи. Оренбургская духовная семинария была основана только в 1884 году, четверть века спустя после создания Оренбургской епархии. В 1908 году Синод раскритиковал Оренбургскую епархию за нехватку «необходимого наблюдения» за староверцами среди уральских казаков и отнял Уральскую область, поместив ее под юрисдикцию Самарской епархии.

Подобный процесс мы можем наблюдать и при отделении Оренбургского учебного округа от Казанского. Предложение, написанное сотрудником генерал-губернатора Николая Крыжановского (18641883 гг.), объясняло необходимость введения Оренбургского учебного округа чрезвычайно большой областью юрисдикции Казанского учебного округа, которая нарушала эффективное функционирование, хотя он также отметил и следующую причину: «Казанский учебный округ имел две задачи: одна из них была свойственна и другим учебным округам, а именно административно-образовательная, и другая, особая по своему характеру, то есть цивилизаторскомиссионерская» [11]. Согласно автору, цивилизаторская роль Казанского учебного округа закончилась, когда факультет восточных языков Казанского университета переехал в Санкт-Петербургский университет в 1854 году. Сейчас, утверждал он, фронт Русской цивилизации лежит еще дальше на востоке, чем Оренбург. Следовательно, «роль цивилизатора должна быть передана новому Оренбургскому округу».

Однако в Оренбурге трудно было организовать даже попечительский совет, так как там не было университета, духовной семинарии, лицея или дворянской школы. Стремление этого провинциального города претендовать на замещающую «цивилизаторскую» роль Казани было незаслуженным.

«Опытный полигон для реформ». К середине XIX века территория с населением в 4200000 человек была разорвана между министерствами; две гражданских губернии находились под юрисдикцией Министерства внутренних дел, территории двух казачьих и Башкирских войск - под юрисдикцией Военного министерства, территории Внутренней Орды и оренбургских киргизов - под юрисдикцией Министерства государственной собственности и Иностранных дел соответственно. В результате персональной (не территориальной) юрисдикции многочисленные министерства интересовались одной и той же территорией, поэтому даже обычные вопросы 
не могли решаться без длительной переписки между министерствами.

Одним из лозунгов в реформах было «преодоление разъединенности властей». С этой целью в 1864 году генерал-губернатор Безак предложил поделить Оренбургскую губернию, ликвидировать Башкирское войско и обратить инородцев, принадлежащих к нему (башкиры, мишари, тептяри и бобыли), в податное сословие и таким же образом ликвидировать Оренбургское казачье войско, чтобы обратить казаков в податное сословие.

В Уфимской губернии могли быть введены земства, так как там было ликвидировано Башкирское войско, в то время как в Оренбургской губернии было довольно сложно согласовать гражданскую и казачью системы управления. В результате земская реформа в этой области была отложена на полвека. В 1890 году тогдашний Оренбургский губернатор даже предложил заново отделить Оренбургскую казачью территорию от гражданской и сформировать независимую область по примеру Дона и Кубани.

Реформы, проходившие в этот период, были составлены, основываясь на территориальном образе, который разделяла центральная и региональная элита Оренбургского региона, нуждающаяся в реформах для того, чтобы ликвидировать корпоративную структуру общества, дорогостоящее попечительство администрации и «разъединенность властей».

«Объект эксплуатации» и «глухая провинция». Эти два образа объединены, потому что регион имел громадные потенциальные ресурсы, но современники не были способны их использовать из-за недостаточных географических исследований. В своем отчете царю за 1867-1868 годы Оренбургский генералгубернатор Крыжановский писал, что территория «еще не достаточно известна и так мало изучается с научной точки зрения, что очень часто мы относимся с подозрением относительно понимания местных особенностей и даже самых обычных статистических данных, когда разрабатываем меры, нацеленные на улучшение жизни населения и для использования природных богатств». Когда Оренбургский учебный округ начал публиковать свой журнал, попечитель округа писал, что целью журнала было не только обсуждение педагогических проблем, но также и продвижение географического описания округа. Он отмечал: «если районы Уральских гор, Пермской губернии и также некоторых частей Оренбурга были более или менее изучены, этого нельзя сказать об оставшихся частях региона, например, Уфимской губернии и Тургайской и Уральской областях».

Пример образа «глухой провинции» можно найти в отчете генерал-губернатора царю за 18671868 годы: «Не только в степи, деревнях и городах Оренбургской и Уфимской губерний, но также и в самом Оренбурге чиновники, как правило, лишены возможности наслаждаться комфортабельной жизнью и общественными развлечениями, которые обязательны для развитых людей, как пища для тела. Если мы примем во внимание то, что в Оренбурге даже самый здоровый человек не может вынести губительный климат и все продукты потребления чрезвычайно дороги, легко понять, почему так сложно найти стоящих людей, кто желал бы приехать сюда и служить, и почему еще более сложно заставить их тут остаться». Такое положение препятствовало занять место Казани в качестве бастиона «цивилизаторов» или контролировать Туркестан из Оренбурга.

Таким образом, среди всех региональных образов Урало-Каспийского макрорегиона самым успешно реализованным был «опытный полигон для реформ». Именно поэтому регион стал одним из двух самых интернациональных периферий Российской Империи (другим исключением была Новороссия). Регион, который изначально был продуктом воображения, получил индивидуальность и даже начал давать роли политикам, к нему относящимся.

В советскую эпоху Урало-Каспийский регион был разрушен новыми административными границами внутри как СССР, так и Российской Федерации. Однако на современном этапе, с началом строительства Евразийского экономического союза, лимогенное состояние Оренбургского региона вновь подпадает и под феномен трансграничности, и под феномен формирования макрорегионального центра, что, несомненно, актуализирует историко-географическое изучение Урало-Каспийского региона.

\section{СПИСОК ЛИТЕРАТУРЫ:}

1. America's Frontier Story. A Documentary History of Westward Expansion. Huntigton, Princeton, 1980. $314 \mathrm{p}$.

2. Замятина Н.Ю. Зона освоения (фронтир) и её образ в американской и русской культурах // Общественные науки и современность. 1998. № 5. С. 12-18.

3. Герасименко Т.И. Этногеографический атлас Оренбургской области. Оренбург: ИПК ГОУ ОГУ, $2015.80 \mathrm{c}$.

4. Трепавлов В.В. История Ногайской Орды. М.: Восточная литература, 2002. 752 с.

5. Илишкин М.Г. Участие ойрат-калмыков в политической истории Тибета [Электронный ресурс] // Буддизм в Калмыкии. - http://buddhisminkalmykia.ru/ $? \mathrm{p}=391$.

6. Карамзин Н.М. История государства Российского. Т. 10. СПб.: Дм. Буланин, 2010. 319 с.

7. Кривощеков А.И. Исторические судьбы Оренбургского края // Вестник Оренбургского учебного округа. 1912. № 2. С. 87-115.

8. Мацузато К. Управляя пространством // Местное управление в пореформенной России: механизмы власти и их эффективность. Сводные материалы заочной дискуссии / под ред. А.Е. Загребина, С.В. Любичанковского. Екатеринбург-Ижевск: Изд-во УрО РАН, 2010. $496 \mathrm{c.}$

9. Добросмыслов А.И. Материалы по истории России. Сборник указов и других документов, касающихся управления и устройства Оренбургского края. Т. 1-2. Оренбург: Губ. типография, 1900.

10. Смирнов Ю.Н. Оренбургская экспедиция (комиссия) и присоединение Заволжья к России в 3040-е гг. XVIII века. Самара: Изд-во «Самарский унT», 1997. $187 \mathrm{c}$.

11. Семенов В.Г. Губернаторы Оренбургского края. Оренбург: Оренбургское книжное издательство, 1999. $400 \mathrm{c}$. 


\title{
URAL-CASPIAN REGION AS A HISTORICAL AND GEOGRAPHICAL PHENOMENON (XVI - THE BEGINNING OF THE XX CENTURY)
}

(C) 2017

\author{
Lyubichankovskiy Sergey Valentinovich, doctor of historical sciences, head of Russian History Department \\ Orenburg State Pedagogical University (Orenburg, Russian Federation) \\ Lyubichankovskiy Alexey Valentinovich, candidate of geographical sciences, researcher, \\ associate professor of Geography and Region Studies Department \\ Orenburg State University, Steppe Institute of Russian Academy of Sciences (Orenburg, Russian Federation)
}

Abstract. This paper deals with cross-disciplinary historical and geographical research. The Ural-Caspian Region existing from the 16th century to the beginning of the 20th century is its main focus. The Assessment of new lands inclusion in the Russian civilization is carried out. The authors analyze the Ural-Caspian Region through assessment of dynamics of its cultural landscapes. The social processes happening in the region are characterized. The authors suggest considering the Ural-Caspian Region as a frontier, existing from the 16th century to the beginning of the 20th century. Ethno cultural space structure mosaicity, original culture of the Cossacks and the zone with special social conditions were characteristics of the Russian and Nogai cultures assimilation at the early stage of the development. The Orenburg Region with its «creeping-away» regional identity is the only outlier of the Ural-Caspian Region. In its population historical memory it is possible to find five spatial images of the Orenburg Region: «base to Central Asia», «citadel of "civilization"», «testing ground for reforms», «operation object with huge resources» and «the deaf province».

Keywords: frontier; cultural landscapes; Ural-Caspian Region; development vector; nomad model; historical and geographical characteristic; civilization; Nogai Horde; assimilation; Orenburg Cossacks; ethno cultural space; regional identity.

УДК 94(410)

\section{ИСТОРИЧЕСКИЕ РОМАНЫ ВАЛЬТЕРА СКОТТА - СУБСТАНЦИАЛЬНЫЙ ФАКТОР ФОРМИРОВАНИЯ ШОТЛАНДСКОЙ НАЦИОНАЛЬНОЙ ИДЕНТИЧНОСТИ НА РУБЕЖЕ ХVIII-XIX ВЕКОВ} (C) 2017

Федорова Татьяна Александровна, аспирант кафедры всеобеей истории, права и методики преподавания Самарский государственный соџиально-педагогический университет (2. Самара, Российская Федераџия)

Аннотация. В данной статье рассматривается влияние исторических романов Вальтера Скотта на формирование национальной идентичности Шотландии на рубеже XVIII - начала XIX века. В свете современной геополитической ситуации, учитывая нарастающую волну сепаратизма, актуальность исследования процесса формирования национальной идентичности трудно переоценить. В статье анализируются исторические предпосылки формирования национального самосознания шотландцев, рассматриваются характерные особенности историко-культурного развития региона. По мнению автора, немаловажное значение в преодолении национальной разобщенности как Шотландии, так и Британии в целом имели работы Джеймса Макферсона и епископа Перси. Особое внимание обращается на роль сэра Уолтера Скотта в процессе национального возрождения Шотландии. Такие романы, как «Уэверли», «Пуритане», «Роб Рой», познакомили широкую публику с ментальным базисом шотландского народа. Раскрыв для широкого круга читателей особенности национального характера, религиозные основы шотландского мировоззрения, автор пробудил интерес британского общества к историческому наследию Шотландии, тем самым заложив основу успешной интеграции двух народов в единую нацию. Сэру Уолтеру Скотту своей работой удалось возродить национальный престиж Шотландии, пострадавший после подписания Унии 1707 года.

Ключевые слова: Горная Шотландия; Равнинная Шотландия; национальная идентичность; конструктивизм; этнос; религиозная идентичность; шотландская баллада; Роб Рой; пресвитерианство; Славная революция; цикл Оссиана; песни шотландской границы.

В современном социокультурном пространстве процесс формирования и трансформации национальной идентичности становится предметом изучения все большего числа исследователей, поскольку именно в национальной идентичности отражается состояние социума, его интегрированность, конформность, способность к консолидации и ценностные ориентации. Учитывая тенденцию к мировой глобализации и, как следствие, нарастающую волну сепаратизма, актуальность исследования путей и способов формирования национальной идентичности сложно переоценить. Именно осознание национальной идентичности скрывает в себе огромный потенциал для преодоления культурной разобщенности и межнациональных конфликтов.

Введение в научный оборот термина «идентичность» принадлежит выдающемуся исследователю в области социальной психологии Эрику Хомбургеру Эриксону [1, с. 23]. Также благодаря работам Э. Эриксона стало широко использоваться понятие «кризис идентичности», который возникает в условиях глубоких общественных трансформаций [2, с. 55]. Дальнейшие исследования в этой области Э. Геллнера $[3$, c. 21], Э. Хобсбаума [4], Б. Андерсона [5] выявили роль государства и интеллектуальных элит в процессе формирование как общегосударственной, так и 